\title{
Antipathetic Effect of Euphorbia Hirta on Staphylococcus Aureus
}

Versha Upadhyay

Uttaranchal P.G. College of Biomedical Science and Hospital, Dehradun, Uttarakhand, India

\begin{abstract}
The use of plant compounds to treat infection is an age old practice in a large part of the world, especially in developing countries, where there is dependence on traditional medicine for a variety of diseases. Euphorbia $s p$. are used in traditional medicines. Hypotensive and tonic properties are also reported in $E$. hirta. The aqueous extract exhibits anxiolytic, analgesic, antipyretic, and anti-inflammatory activities. Methanolic extract of leaves have antifungal and antibacterial activities. In this work different concentration shows as 100, 75, 50, 25\% and under controlled gave inhibition zone as 9.33, 6.02, 4.48, 3.66 but controlled patriplaite full of microorganism.
\end{abstract}

Keyword: Euphorbia Hirta, Antimicrobial, Staphylococcus Aureus

\section{INTRODUCTION}

Medicinal plants have played an essential role in the development of human culture. This is the reasons for the usage of specific medicinal plants for treatment of certain diseases were being discovered; thus, the medicinal plants' usage gradually abandoned the empiric framework and became founded on explicatory facts. Plants had been the source of treatment and prophylaxis (Huang, et.al.2012).). Since time immemorial people have tried to find medications to alleviate pain and cure different illnesses. In every period, every successive century from the development of humankind and with the advancement of civilizations, the healing properties of certain medicinal plants were identified, noted, and conveyed to the successive generations Tarek A et. al.(2017).

The use of plant compounds to treat infection is an age old practice in a large part of the world, especially in developing countries, where there is dependence on traditional medicine for a variety of diseases (Martins Ekor, 2013). According to World Health Organization, medicinal plants would be the best source of Ayurveda In recent years, antimicrobial properties of medicinal plants are being increasingly reported from different parts of the world (Haidan,2016). Antimicrobial plant extracts have been recognized as a future source of new antimicrobials in the event of the current downturn in the pace at which these are being derived from micro-organisms.(Desalegn Amenu 2014).

Euphorbia hirta is a small annual herb common to tropical countries Mohammad ,(2010). It can grow to a height of $40 \mathrm{~cm}$. The stem is slender and often reddish in colour, covered with yellowish bristly hairs especially in the younger parts. The leaves are oppositely arranged, lanceolate and are usually greenish or reddish underneath measuring about 5 $\mathrm{cm}$ long. In the axils appear very small dense round clusters of flowers. The small green flowers constitute the inflorescence characteristic of the euphorbia's. The stem and leaves produce white or milky juice when cut Anononymous.(2005). Euphorbia hirta is annual weed mostly found on road side. The plant widely used in traditional medicinal to cure various disease especially for gastrointestinal disorder, skin disease etc.(Huang et al., 2012). E. hirta is mostly 
contain gallic acid, quercetin and a phenolic substance $\mathrm{C} \mathrm{H} \mathrm{O}$. Several studies conclude that $E$. hirta possess 281815 anti-anaphylactic, antioxidant, anticancer, antifeedant, antiplatelet aggregation and anti-inammatory, aatoxin inhibition, antifertility, antiplasmodial, antiamoebic, larvicidal, and insect repellent activities (Sandeep and Chandrakant, 2011).

\section{Plant material : Morphology of plant material:}

E. hirtabelongs to the plant

family Euphorbiaceae and genus Euphorbia. It is a slender- stemmed, annual hairy plant with many branches from the base to top, spreading upto $40 \mathrm{~cm}$ in height, reddish or purplish in color. Leaves are opposite, elliptic - oblong to oblong- lanceolate, acute or subacute, dark green above, pale beneath, 1- 2.5 $\mathrm{cm}$ long, blotched with purple in the middle, and toothed at the edge. The fruits are yellow, threecelled, hairy, keeled capsules, 1-2 mm in diameter, containing three brown, four-sided, angular, wrinkled seeds Rahman et. al.2013), Hussain et. al. 2014.) The collected plants were dried under shade, crushed and subject to soxhlet extraction with methanol.

\section{Morphology of bacteria}

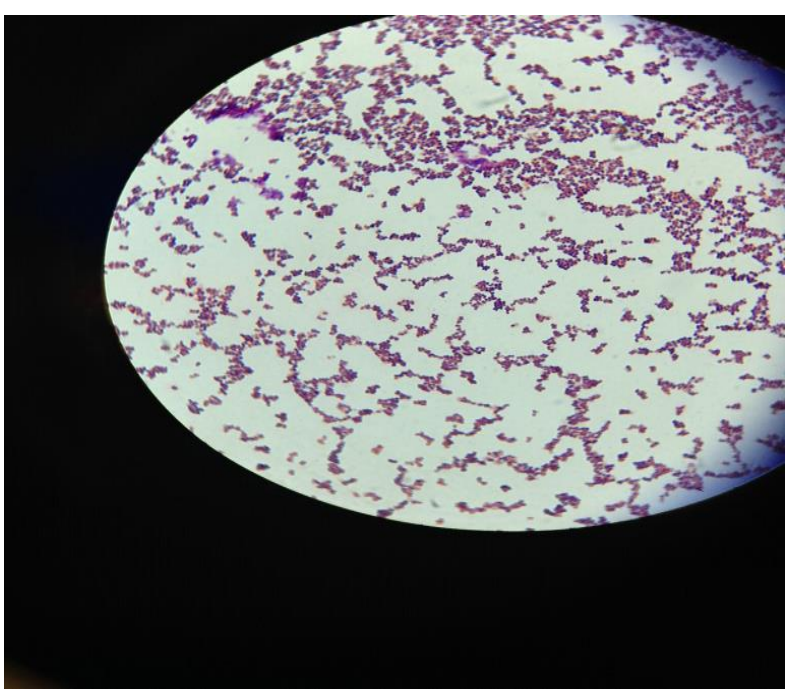

Figure 1. Strain of $S$.aureus.
Staphylococcus was first identified in 1880 in Aberdeen, Scotland, by surgeon Sir Alexander Ogston in pus from a surgical abscess in a knee joint. This name was later amended to Staphylococcus aureus by Friedrich Julius Rosenbach, who was credited by the official system of nomenclature at the time ( Ogston ,1984). S. aureus can cause a range of illnesses, from minor skin infections, such as pimples, impetigo, boils, cellulitis, folliculitis, carbuncles, scalded skin syndrome, and abscesses, to life-threatening diseases such as pneumonia, meningitis, osteomyelitis, endocarditis, toxic shock syndrome, bacteremia, and sepsis. It is still one of the five most common causes of hospital-acquired infections and is often the cause of wound infections following surgery (Singh et.al.2018). S.aureus is not always pathogenic, it is a common cause of skin infections including abscesses, respiratory infections such as sinusitis, and food poisoning. Pathogenic strains often promote infections by producing virulence factors such as were collected potent protein toxins, and the expression of a cell-surface protein that binds and inactivates antibodies (Abeer2016). The emergence of antibiotic-resistant strains of $S$. aureus such as methicillin-resistant $S$. aureus is a worldwide problem in clinical medicine. Despite much research and development there is no approved vaccine for $S$. aureus (Tracey et.al.2018)

\section{MICRODILUTION METHOD}

\section{PRINCIPLE}

Dilution susceptibility testing methods are used to determine the minimal concentration of antimicrobial needed to inhibit or kill the microorganism. This can be achieved by dilution of antimicrobial in either agar or broth media Vineetha et. al.(2015). 


\section{PROCEDURE}

The minimum inhibitory concentration (MIC) was determined by micro dilution method using serially diluted plant extracts. The methanol extract were diluted to get series of concentrations from $25 \%, 50 \%, 75 \%$ and $100 \%$ respectively in distilled water. The microorganism suspension of $50 \mu$ was added to the broth dilutions. These were incubated for 18 hours at $37 \circ \mathrm{C}$. MIC of each extract was taken as the lowest concentration that did not give any visible bacterial growth. E. L. Chuah(2014).

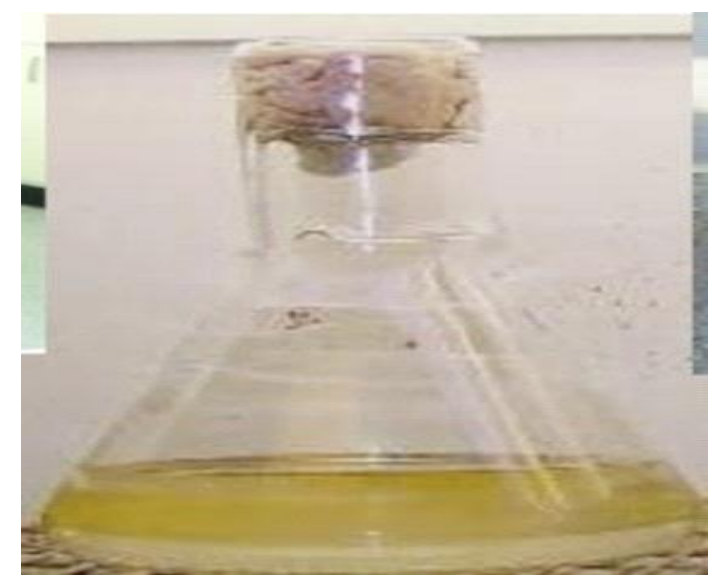

(A)

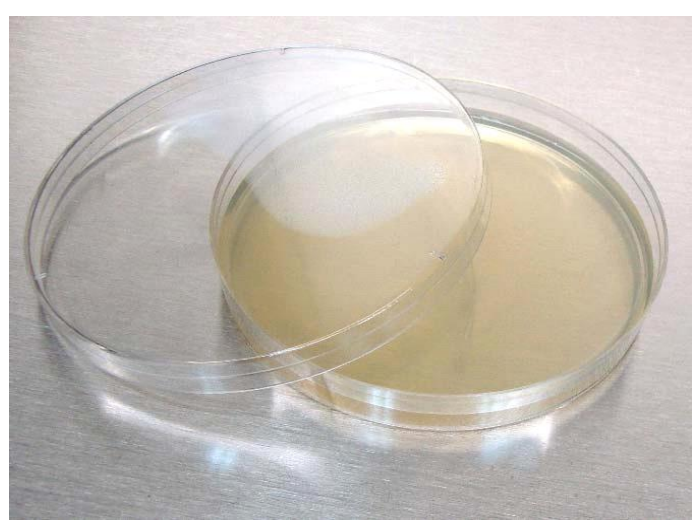

(B)

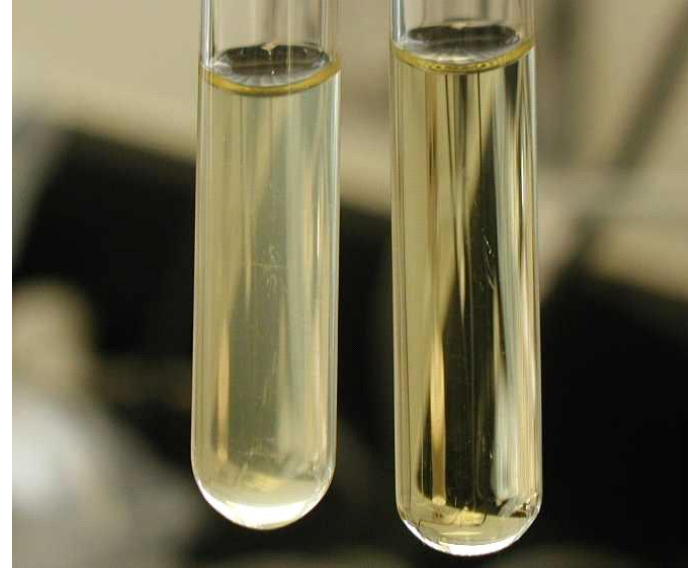

(C)

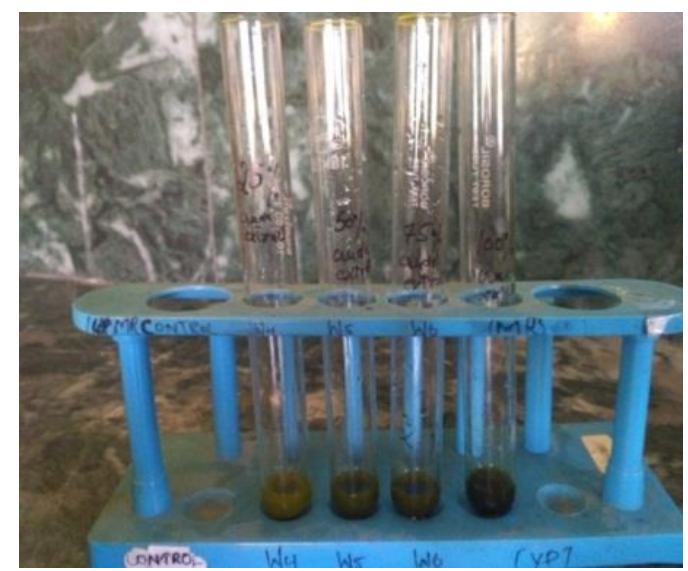

(D)

Figure 2 (a) MHA (250ml), (b) MHA Plate, (c) Nutrient broth \& (d)Test tubes containing crude methanolic extract of E. hirta with different concentrations.

\section{Evaluation of antibacterial activity}

The effect of various plant extracts on the several bacterial strains were assayed by Agar well diffusion method and further confirmed by disc diffusion method. The minimum concentrations of the plant extracts to inhibit the microorganisms were also determined by microdilution method using plant fractions serially diluted in sterile nutrient broth.

Bacterial cultures of that were used for antimicrobial assay of test organisms were obtained from the culture collection, UCBMSH, Dehradun. The bacteria 
were maintained on nutrient broth $(\mathrm{NB})$ at $37^{\circ} \mathrm{C}$ till required for analysis.

\section{AGAR WELL DIFFUSION METHOD PRINCIPLE}

The antimicrobials present in the plant extract are allowed to diffuse out into the medium and interact in a plate freshly seeded with the test organisms. The resulting zones of inhibition will be uniformly circular as there will be a confluent lawn of growth. The diameter of zone of inhibition can be measured in millimeters.

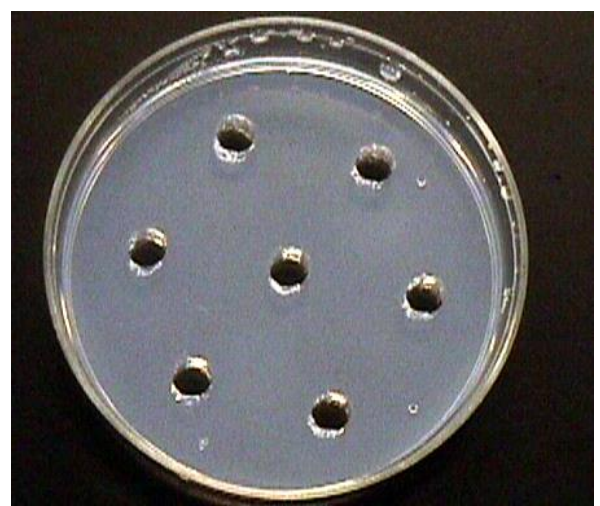

Figure 3. Plate showing wells made with borer

\section{PROCEDURE}

Petriplates containing 20ml Muller Hinton medium were seeded with $24 \mathrm{hr}$ culture of bacterial strains. A sterile swab stick was used to spread about $0.2 \mathrm{ml}$ of the standardized test inoculum evenly on the surface of the solidified media. Five equidistant wells of 5 $\mathrm{mm}$ in diameter were then made on the seeded agar plate using a sterile cork borer and the plant extracts with concentrations ranging from $25 \%, 50 \%, 70 \%$ and $100 \%$ respectively, were introduced into the bored holes. A $5 \mathrm{ml}$ of tween 20 was used in reconstituting the extracts. The plates were then incubated at $37^{\circ} \mathrm{C}$ for 24 hours. The antibacterial activity was assayed by measuring the diameter of the inhibition zone formed around the well (NCCLS, 1993).

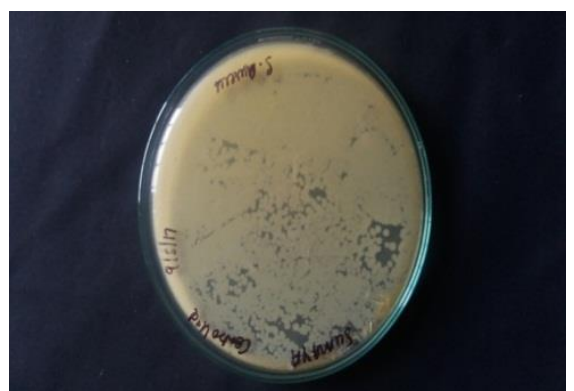

(a)

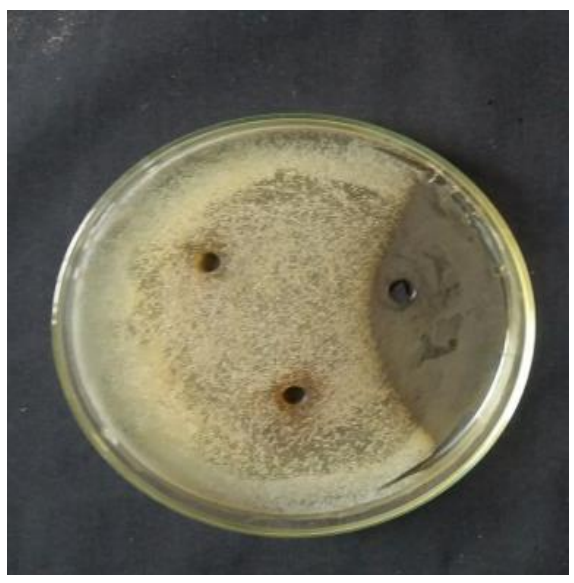

(b)

Figure 4. (a) culture plate (b) inhibition zone

\section{RESULTS AND DISCUSSION}

Results of the antibacterial screening of different concentrations of the extracts on the test isolates are shown in Table 1 and Graph1. The results show that the increase in concentration of the extract increased the zones of growth inhibition of the bacteria (Fig. 5 b). The assessment of the antibacterial activity was based on the measurement of diameter zone of inhibition $(\mathrm{mm})$ that formed around the hole made by the borer filled with the extract. Maximum inhibition zone was recorded at $100 \mathrm{mg} / \mathrm{ml}$ and the minimum inhibition zone at $25 \mathrm{mg} / \mathrm{ml}$ in both the bacteria for all the extracts and controlled petriplates showed no zone of Inhibition (Table 1 and 2; Fig 5a and $b$ ). This proved that the extract is effective against microbes. 


\begin{tabular}{|c|c|}
\hline $\begin{array}{c}\text { Concentrations of } \\
\text { Euphorbia hirta extract } \\
(\mathrm{mg} / \mathrm{ml})\end{array}$ & $\begin{array}{c}\text { Zone of Inhibition } \\
\text { (mm) in } \\
\text { Staphylococcus } \\
\text { aureus }\end{array}$ \\
\hline 100 & 9.33 \\
\hline 75 & 6.02 \\
\hline 50 & 4.48 \\
\hline 25 & 3.66 \\
\hline
\end{tabular}

Table 1. Zone of Inhibition in S.aureus

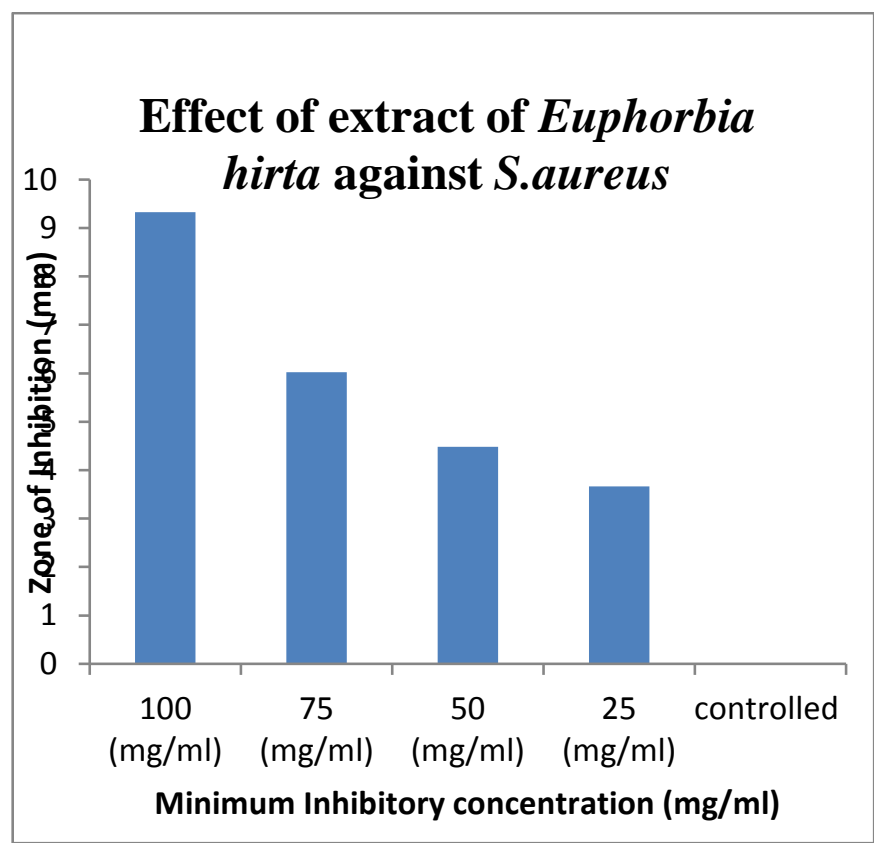

Graph 1. Effect of extract of Euphorbia hirta against S.aureus

\section{IV.CONCLUSION}

In this study, the results indicated that the methanolic extract of the plants inhibited the growth of the test bacteria. This therefore, showed that the extract contained substances that can inhibit the growth of the selected bacteria. Other workers have also shown that extracts of plants inhibit the growth of various microorganisms at different concentrations (Faraja et al. 2018).

\section{REFERENCES}

[1]. Abeer A. Abu Zaid, Nashwa A. Ezzeldeen, Friba A. Nazar (2016).Antibacterial effect of some types of nanoparticles against methicillinresistant Staphylococcus aureus isolated from milk. International Journal of Pharmaceutical Research \& Allied Sciences, 5(1):122-134.

[2]. Anononymous.(2005). The use of Euphorbia hirta in the treatment of sores boils and wounds. Personal communication with the Chairman, Imo state Traditional Medicine Practioners: Owerri Nigeri;..

[3]. Desalegn Amenu(2014) Antimicrobial Activity of Medicinal Plant Extracts and Their Synergistic Effect on Some Selected Pathogens American Journal of Ethnomedicine, Vol. 1, No. 1, 018-029.

[4]. E. L. Chuah, Z. A. Zakaria Z. Suhaili S. Abu Bakar M. N. M. Desa. (2014) Antimicrobial Activities of Plant Extracts against MethicillinSusceptible and Methicillin-Resistant Staphylococcus aureus Journal of Microbiology Research, 4(1): 6-13 DOI: 10.5923/j.microbiology.20140401.02

[5]. Faraja D. Gonelimali, Jiheng Lin, Wenhua Miao, Jinghu Xuan, Fedrick Charles, Meiling Chen, andShaimaa R. Hatab (2018).Antimicrobial Properties and Mechanism of Action of Some Plant Extracts Against Food Pathogens and Spoilage Microorganisms Front Microbiol. 24. doi: 10.3389/fmicb.2018.01639.

[6]. Haidan Yuan, Qianqian Ma , Li Ye and Guangchun Piao (2016). The Traditional Medicine and Modern Medicine from Natural Products Molecules 21,559; doi:10.3390/molecules 21050559 .

[7]. Huang, L., Chen, S. and Yang, M. (2012). Euphorbia hirta (Feiyangcao): A review on its 
ethnopharmacology, phytochemistry and pharmacology. Journal of Medicinal Plants Research. 6(39):5176-5185.

[8]. Hussain, M., Farooq, U., Rashid, M., Bakhsh, H., Majeed, A., Khan, I.K., Lati, S., Shafeeq-urRahman, M., Aziz, A. (2014). Antimicrobial activity of fresh latex, juice and extract of Euphorbia hirta and Euphorbia thymifolia - an in vitro comparative study. International Journal of Pharma Sciences. 4(3): 546-553.

[9]. Martins Ekor (2013).The growing use of herbal medicines: issues relating to adverse reactions and challenges in monitoring safety. doi: 10.3389/fphar.2013.00177.

[10]. Mohammad Abu Basma Rajeh, Zakaria Zuraini , Sreenivasan Sasidharan, Lachimanan Yoga Latha and Santhanam Amutha (2010), Assessment of Euphorbia hirta L. Leaf, Flower, Stem and Root Extracts for Their Antibacterial and Antifungal Activity and Brine Shrimp Lethality. Molecules 15, 6008-6018; doi: 10.3390/molecules 15096008 .

[11]. National committee for clinical Laboratory Standards (1993). Performance standards for Antimicrobial Disc Suspectibility Tests. Approved Stander NCCLS Publication Disc M2A5, Villllanova,PA,USA.

[12]. Ogston A (1984) On abscesses. Classics in infectious diseases. Rev Infect Dis 6: 122-128.

[13]. Rahman A.H.M. Mahbubur , Akter Momota (2013).Taxonomy and Medicinal Uses of Euphorbiaceae (Spurge) Family of Rajshahi, Bangladesh. Research in Plant Sciences, 2013, Vol. 1, No. 3, 74-80 .

[14]. Singh Balvindra ,Singh Neelam,singh , Raghuvendra (2018). Isolation of Staphylococcus and gram-negative bacteria from the hospitalized area and screening bacteria against various plant extract. International Journal of Medical Science and
Clinical Invention 5(03): 3619-3624, DOI:10.18535.

[15]. Tarek A El-Bashiti Emad Abou Elkhair Wesam S Abu Draz (2017).The antibacterial and synergistic potential of some Palestinian plant extracts against multidrug resistant Staphylococcus aureus. Journal of Medicinal Plants Studies 5(2): 54-65.

[16]. Vineetha, N., Vignesh RA,Sridhar,D. (2015).Preparation, Standardization of Antibiotic Discs and Study of Resistance Pattern for First-Line Antibiotics in Isolates from Clinical Samples International Journal of Applied Research; 1(11): 624-631.

\section{Cite this article as :}

Versha Upadhyay, "Antipathetic Effect of Euphorbia Hirta on Staphylococcus Aureus", International Journal of Scientific Research in Science and Technology (IJSRST), Online ISSN : 2395-602X, Print ISSN : 2395-6011, Volume 6 Issue 4, pp. 21-26, JulyAugust 2019. Available at doi : https://doi.org/10.32628/IJSRST18401137 Journal URL : http://ijsrst.com/IJSRST18401137 